\title{
Informational Status of Translation Errors and Translation Quality Assessment
}

\author{
Tamara A. Kazakova a and Olga V. Algina ${ }^{\mathrm{b} *}$ \\ ${ }^{a}$ St. Petersburg State University, \\ 7/9 Universitetskaya nab., St. Petersburg, 199034, Russia \\ ${ }^{b}$ Peter the Great St. Petersburg Polytechnic University \\ 29 Polytechnicheskaya Str., St. Petersburg, 195251, Russia
}

Received 10.04.2018, received in revised form 18.04.2018, accepted 25.04.2018

The survey is to verify the hypothesis of correlation between different types of translation errors and the reaction of target readers of newspaper articles to possible shifts of information caused by such errors. Considering different approaches to translation quality assessment (TQA), we analyze typical translation errors from the viewpoint of logical, emotive, expressive and other losses and/or distortions of the source information found in the target text. The preliminary results were compared with readers' comments on both source and target texts. The divergence of readers' reactions appeared to be rather narrow and only in part correlated with the major and even critical mistakes made by translators.

Keywords: translation error, translation quality assessment, informational shifts and distortions.

DOI: 10.17516/1997-1370-0266.

Research area: linguistics.

\section{Introduction}

Undoubtedly, mass media influence our mind and form our opinion about a particular subject to a considerable degree. Evidently, every word used by the author of the article is oriented at making readers adhere to the opinion of this particular author or the newspaper. Can translation interfere into the process and influence target readers accordingly but in a different way? In the era of informational warfare, the newspaper translation and its quality is as pivotal as it has never been for mass media can form the reader's attitude to this or that problem as required by political tendencies.
However, the meaning of the source message is often distorted due to linguistic and cultural differences, let alone intentional/unintentional shifts caused by the translator's interpretation that is an inevitable part of translation. This article considers a certain range of differences between English newspaper items and their translations into Russian. The objective of our survey is to detect shifts in translation and compare them with the differences in reaction to the problem between English and Russian readers. Using different tools of translation quality assessment (TQA), we compare the source newspaper article

(C) Siberian Federal University. All rights reserved

* Corresponding author E-mail address: tamakaza@gmail.com; albukova.olga@yandex.ru 
and its translation, evaluating differences in meaning between ST and TT in correlation with readers' opinion.

\section{Approaches to TQA}

The diversity of approaches to TQA mainly correlates with those to the concept of equivalence. In 1965, J. Catford differentiated between formal correspondence and textual equivalence (Catford, 1965: 23-25). Later, his differentiation was criticized for using too simplified examples (Kenny, 2001; Snell-Hornby, 1995). Nevertheless, those ideas found the development in splitting between linguistic and communicative approaches. For instance, M. Baker adheres to a linguistic-oriented approach. She distinguishes seven levels of equivalence: equivalence at word level, equivalence above word level, grammatical equivalence, thematic and information structures equivalence, textual equivalence and pragmatic equivalence (Baker, 2011). M. Baker thoroughly describes each type of equivalence and provides examples of translation strategies at each level. L. Venuti (Venuti, 1999) rejects her approach and points out that although the linguistic-oriented theory used by M. Baker is based on the Gricean model of four maxims (quantity, quality, relation, and manner) (Grice, 1975), yet some of these maxims can be violated in the translation process since, according to Venuti, they can differ within a community (for example, the maxim of quantity is violated when the translator needs to add a footnote or a comment to compensate for any kind of implicatures) (Venuti, 1999: 22). Venuti proves that in translation the communicative evaluation is as important as linguistic.

A. Pym introduces the concept of natural and directional equivalence. Natural equivalence presupposes that both source text and translated text should have the same value, which "does not say that languages are the same; it just says that values can be the same" (Pym, 2014: 21).
Presumably, equivalence can be "established on any linguistic level, from form to function" as well as this type of equivalence "should be the same whether translated from language A into language B or the other way round" (Pym, 2014: 21). Directional equivalence is described by Pym as asymmetric: "the creation of an equivalent by translating one way does not imply that the same equivalence will be created when translating the other way" (Pym, 2014: 46). He also adds that translators have a lot of choices: they can choose any strategy they think is appropriate; yet he mentions "a choice made by the translator, a choice not necessarily determined by the text translated" (Pym, 2014: 57). Is such a choice necessarily wrong? It only means that we can face shifts in translation caused by the choice of wrong strategies or misunderstanding.

J. House elaborated a well-balanced model for TQA considering equivalence to be a cornerstone of any translation; she defines translation as the replacement or recontextualization (House, 2001: 247) of a text in "the source language by a semantically and pragmatically equivalent text in the target language. An adequate translation is, then, a pragmatically and semantically equivalent one" (House, 2015: 63). She emphasizes the significance of function equivalence defined as "the application or use of the text in a particular context of situation" according to the pragmatic approach (House, 2001: 248). Function equivalence must correlate with a particular situation or context of a situation that includes such situational dimensions as field, tenor and mode (House, 2001: 248). After Schleiermacher's distinction between foreignization and domestication in translation, J. House develops the idea of overt and covert translation. According to the author, the overt translation is accepted by the target reader as a translation, which does for translation of specific texts (e.g. historical or aesthetic) where a "precisely specified source 
language audience is being addressed" (House, 2015: 66). The covert translation on the contrary is perceived by the target reader as an "original source text in the target culture" (House, 2015: 66), The overt translation is described within the framework of a four-level analytical model that includes Function-Genre-Register-Language/ Text and is placed at the level of Language/ Text, Register, Genre. The covert translation is represented at the levels of Language/Text, Genre, Register through a "cultural filter" (House, 2001: 250). House argues that we should take into account the type of translation assessed (overt or covert), since these two types require different strategies of assessment. Notably, researchers differ in views on this issue: some concede the existence of overt and covert translations, while others give preference to foreignization so that target readers could see differences in cultures (Venuti, 1995).

Another viewpoint on TQA was developed by K. Reiss who, together with H. Vermeer, adheres to the Skopos theory. She says that a text should be translated according to its function, so a translated text should be assessed according to its function. Reiss points out that it would be wrong to apply the same criteria of TQA to scientific works, fiction, opera librettos, etc. She offers to assess target texts in accordance with their function. Reiss distinguishes three textual functions: depictive, expressive, and persuasive (Reiss, 2000: 25).

C. Nord follows the concept of the Skopos theory, where the most important notions to her are aim, purpose function and intention. The author also marks out four textual functions that can evoke some problems in translation: the phatic function, the referential function, the expressive function, the appellative function. In her work, Nord considers some translation problems posed by different text types but does not propose any TQA scaling (Nord, 2006; 2014).
S. Halverson presents a cognitive approach to translation shifts and points out three most important fields such as cognition, convention and context where a translator can face some difficulties and where all kinds of translation errors take place (Halverson, 2001: 105-121).

T.A. Kazakova offers an informational model to be used in translation and assesses translations according to the comparative amount of information that is present in ST and TT. The author emphasizes that any meaning is information based on reasoning as well as on "feelings, imagination, experiences" (Kazakova, 2015: 2843). She distinguishes two types of information that are essential for translation and translation assessment: objective information that includes linguistic information such as style, lexicon, grammar, cultural (social-historical) and subject matter. Subjective information includes "the impact of the text on the reader conditioned by the author's personal implication (it may not coincide with the standard associations and meanings) as well as by the reader's personal experience and imagination" (Kazakova, 2015: 2844). The translator processes all those informational components using a number of tools, among them the observer strategies (the impersonality of choices and indifference to the supposed reader) and helper strategies (i.e. biased strategies aimed at educating the target reader and providing him with additional information) (Kazakova, 2015: 2846). The observer strategy may result in losing such informational components as emotive, expressive or aesthetical information. On the contrary, the helper strategy may exaggerate or overdramatize this or that aspect of the source informational structure.

The argumentative concept of TQA was offered by M. Williams (Williams, 2003). M. Williams insists that a translated text should be assessed in accordance with two discourse categories: 1) argument macrostructure which includes claim/ 
discovery, grounds, warrant, backing, qualifier/ modalizer, rebuttal/exception, and 2) rhetorical typology (Williams, 2001: 336-342). The assessor should check the presence of all these components of the argumentation macrostructure. Then the evaluator should "establish, through comparative reading, to what extent the argument macrostructure is reflected in TT" (Williams, 2001: 336-342). If one of the components of argumentation macrostructure is present in ST but missed in TT, this error is critical. In his work, Williams established three types of errors: critical errors that include mistakes made at the textual level, major mistakes which do not distort the meaning of the original text and minor errors dealing with a stylistic component of the word.

\section{Materials and discussion}

Here we analyze the translation of the article entitled Russia's ban on US adoption isn't about children's rights (Запрет на усыновление не связан с правами детей) by Laurie Penny from The Guardian. The article considers the tragedy that took place in July 2008: a little Russian boy, Dima Yakovlev, adopted by an American couple, was left in a closed car for several hours on a hot summer day. The boy died, but his adopted parents were acquitted by the American court. In 2012, the Russian government passed the Dima Yakovlev Law. Curiously enough, this act was qualified as a retaliation to the American Magnitsky Act passed earlier while its relation to children's rights was hushed up.

The translation of the article includes some minor and major errors as well as two critical errors that can impede a reader from the correct understanding of the text. The first paragraph is about measures undertaken, according to the author, just to ruin lives of ordinary people and children:

Laurie Penny:

Perhaps this how the cold war really ends: not with a bang, but a series of petty policy disputes that savage individual lives and leave both countries looking sordid.

Russian (anonymous) translation:

Наверное, именно так заканчивается холодная война: не громом салюта, а чередой разрушаюших жизни людей мелких споров, на фоне которых обе страны выглядят жалко и отвратительно.

Back (our) translation:

Perhaps, this is the way how the cold war ends: not with the thunder of salute, but a series of petty disputes ruining people's lives against the background of which both countries look sordid and disgusting).

The anonymous Russian translator made several apparent errors that cause informational distortion in the message.

First, the translator failed to recognize the allusion to Eliot's famous poem The Hollow Men, where impersonal people are paralyzed by a certain shadow and now cannot create or live on their own any longer, so the world they live in is deemed to self-destruction. The phrase alluded to by Laurie Penny runs as follows: This is the way the world ends/This is the way the world ends/This is the way the world ends/Not with a bang but a whimper (Eliot, https://allpoetry.com/ The-Hollow-Men). The most popular (though not the most elegant) Russian translation of this poem says, Вот как кончится мир/Вот как кончится мир/Вот как кончится мир/Не взрыв но всхлип. (translated by A. Sergeev). Evidently, the translator did not recognize the paraphrased citation and failed to reproduce it in the target text. Yet the failure is only the surface while the major loss is meaning since it has lowered expressive and emotional colouring of the phrase, which is inadmissible because it causes the distortion of cultural (expressive, 
emotive and aesthetic) components of the source message as well as its negative logical correlation with the meaning of ruin (i.e. the metaphor bang - ruin) and thus betrays the target reader. What is more important and refers to reasoning is that the word bang (взрыв, in Russian) is not a thunder of salute (the sound of celebration), but explosion (the sound of destruction, ruin). In our judgment such mistakes belong to the category of crucial (by Williams, see above).

Another significant error is the omission of the word policy in translation, a meaningful informational unit suggesting that petty policy disputes can ruin people's lives (actually, political incoherence can destroy the normal course of life), while the Russian variant mentions petty rows and quarrels (actually, domestic squabbles). Thus, the omission unreasonably diminishes the worldwide scale of events making another step towards the distortion of the original information.

The following error may seem minor but it is not: a single word sordid splits into two synonyms («жалко и отвратительно») in translation. Such a shift seems a mere stylistic imperfection pleonasm. Yet it is not just pleonasm but also a shift of meaning resulting in the distortion of logical information. The source word sordid includes such connotations as immoral or dishonourable actions and motives; arousing moral distaste and contempt while the target variant includes such words as «жалко и отвратительно» connoted with abject and detestable rather than immoral behaviour. These meanings appear in bilingual dictionaries as correlated but do not coincide in definitions. Thus, apart from unnecessary synonyms, the target text includes incoherent axiological connotations, which moves the mistake from the class of stylistic shifts into the class of meaningful distortions.

Some shifts look like interlingual synonyms but in certain contexts are perceived as factual mistakes. Among other topical issues in her article, Laurie Penny writes about safety of adopted children. In particular, she says that the Hague Convention on international adoption was not ratified by Russia, which prevents the Russian government from protecting Russian children adopted abroad against domestic violence. The only way to secure children's rights is to ratify the Convention.

English text:

One of the many things that makes the Hague relatively toothless is that Russia has not ratified the treaty.

Russian (anonymous) translation:

Один из моментов, из-за которого конвенция кажется довольно беззубой, состоит в том, что Россия этот договор не подписала.

Back (our) translation

One of the moments due to which the convention seems to be toothless enough is that Russia did not sign this treaty.

Evidently, the translator made a critical error and distorted the meaning of the whole sentence, thus misleading Russian readers. The words sign and ratify may be, to a certain degree, regarded as synonyms within the language system but the difference between them is significant in the aspect of law. According to OED, to sign means to authorize (a document or other written or printed material) by attaching a signature, and to ratify means to sign or give formal consent to (a treaty, contract, or agreement), making it officially valid. Besides, they have different meanings in international practices. In European terms, to sign a treaty means that one of the parties is interested in this particular document and that it will possibly comply with its terms. However if a document is signed but not ratified it means that a nation has a legal right to not fulfill terms of the treaty. The terms of the treaty come 
into force just after ratification that requires a parliamentary approval. Russia signed the Convention in 2000 but never ratified it (https:// www.hcch.net/en/instruments/conventions/ status-table/?cid=69). From this point of view, the translation has distorted not only the vocabulary but the very meaning of the English sentence, which was noted by readers in their comments who accused the author and, then, the translator in incompetence. And yes, we cannot blame the translator in distortion of the information since the author herself makes a similar factual mistake in the next paragraph: If it really cares about its kids, all Russia needs to do is to sign the Hague convention. Actually, Russia signed but not ratified the Hague treaty, which Laurie Penny ignored in her article. By the way, that was noted by both English and Russian readers in their comments to the article as well. Perhaps the original ambiguity influenced the choice of the translator? Anyhow, the word to ratify should have been translated as ратифицировать.

These and similar transformations in Penny's article when translated from English into Russian may appear to be smaller shifts in style, vocabulary or grammar but turn out to become critical distortions when thoroughly compared and correlated with readers' comments.

Exploring comments to the article and its translation we found statements that coincide in part: e.g., both parties agree that the pass of the adoption ban is about politics, but not children's rights; as for the Dima Yakovlev Law, some English readers say that Russia has the right to act as it wants, while some say that it should not have passed the ban. Some English comments say that the article has an anti-American orientation, like "America's concept of itself as a benevolent superpower is so often at odds with reality". Some readers condemn American racism and some disagree with this position. Among English comments, there also were negative remarks about the president of Russia. Making out the regular occurrence, we can say that more remarks of English readers relate to the issue itself and express divergence of opinion. Few of them relate to the author's factual incorrectness such as her reference to the American trend to adopt only white children.

Among readers' comments to the Russian translation, some axiological shifts or even distortions are not noticed by Russian readers, anyhow the comments do not correlate with any particular attitude to the text. For example, subjective additions do not arouse Russian readers perhaps due to their belief that western journalists are always ready to drop derogative or subjective remarks about Russia. Actually, when the translator overemphasizes an expression or adds unnecessary negative judgements that does not cause a particular reaction; evidently, Russian readers ascribe them to the author of the source text. Comments mainly relate to the issues of children's rights: whether the introduction of the adoption ban was a right step or not; whether President Putin was right or not; whether American families should adopt Russian children or not. One comment concerns anti-American orientation and another one to the racism of Americans in the practice of adoption as presented in the article.

\section{Conclusion}

Different types of translation errors can appear in the process of translation caused by the inevitability of the interpretative factor and relativity of translator solutions. They can be minor errors that shift only stylistic level of the text, although even minor shifts may correlate with unjustified emphasis or addition, unwanted axiological connotation or even deviation from the source meaning. Major translation errors, e.g. omissions, can significantly influence the meaning of the text but do not distort its basic 
informational potential. Critical errors that distort considerably the general meaning of a part of the text (or even the whole text), for example, the abuse of transposition, factual shifts or wrong substitutes for keywords. Interpreting the general and partial components of the source information in comparison with expressive potential of the target language the translator may judge right or wrong. Among helpful tools that allow to avoid wrong solutions there are certain strategies the translator can choose. One is that of the observer (you keep to the correlation between SL and TL units from the point of view of their informational compatability). Another one is that of the helper who takes into consideration the target reader. However, any useful strategy requires awareness of the discourse, which is especially significant in the case of media texts where nuances of expression often have a meaningful value.
Here we have discussed some examples of translation solutions that can affect target readers' perception of the article in part or in whole. We supposed that the reaction of the target reader would be more negative to the content of the article due to inappropriate additions, omission of the words or axiological incoherence that may misrepresent the original message. Surprisingly, exploring the correlation between the distorted text and target readers' comments, we see that readers do not seem to notice some distortions and assume the target text for granted perhaps due to the habitual expectation of some adverse if not hostile attitude to Russia from western authors. At the same time, there are certain differences in perception of the source text by English readers and target text by Russian readers especially as far as axiological judgements are concerned.

\section{References}

Baker, M. (2011). In Other Words. A Coursebook of Translation. London; New York: Routledge, Taylor\&Francis Group, $332 \mathrm{p}$.

Catford, J.C. (1965). A Linguistic Theory of Translation. Oxford: Oxford University Press, 103 p.

Grice, H.P. (1975). Logic and conversation. In Syntax and semantics, 3, ed. by P. Cole and J.L. Morgan, N.Y.: Academic Press, 41-58.

Halverson, S.L. (2007). A Cognitive Linguistic Approach to Translation Shifts. In Belgian Journal of Linguistics, 105-121.

House, J. (1997). Translation Quality Assessment: A Model Revisited. Tübingen: Günter Narr Verlag, 209 p.

House, J. (2001). Translation Quality Assessment: linguistic Description versus Social Evaluation. In Meta: Translator's Journal, XLVI (2), Montréal: Les Presses de l'Université de Montréal, 243-256.

Kazakova, T.A. (2015). Strategies of Literary Translation. In Journal of Siberian Federal University. Humanities \& Social Sciences, 8 (12), Krasnoyarsk: Siberian Federal University, 2842- 2847.

Kenny, D. (2001). Equivalence. In Routledge Encyclopedia of translation studies, ed. by M. Baker. London; New York: Routledge, Taylor\&Francis Group, 77-80.

Nord, Ch. (2006). Translating as a Purposeful Activity: a Prospective Approach. In TEFLIN Journal, 17 (2), 131-143.

Nord, Ch. (2014). Translating as a Purposeful Activity: Functionalist Approaches Explained. Florence, KY, USA: Routledge, $161 \mathrm{p}$.

Pym, A. (2014). Exploring Translation Theories. London, New York: Routledge, 255 p. 
Reiss, K. (2000). Translation Criticism - the Potentials \& Limitations. Categories and Criteria for Translation Quality Assessment. London, New York: Routledge, 127 p.

Snell-Hornby, M. (1988/1995). Translation Studies: An Integrated Approach. Amsterdam/ Philadelphia: John Benjamins Publishing Company, 173 p.

Venuti, L. (1999). The Scandals of translation. London; New York: Routledge, Taylor\&Francis Group. 210 p.

Venuti, L. (1995). The Translator's Invisibility. London; New York: Routledge, Taylor\&Francis Group, 353 p.

Williams, M. (2001). The application of argumentation theory in translation quality assessment. In Meta: journal des traducteurs/Meta: Translators' Journal, 46 (2), Montréal (Canada): Université de Montréal, 326-344.

Williams, M. (2004). Translation Quality Assessment: An Argumentation-Centered Approach. Ottawa: Univeristy of Ottawa Press, 188 p.

\title{
Информационный статус переводческих ошибок
}

\section{и оценка качества перевода}

\author{
Т.А. Казакова ${ }^{a}$, О.В. Альгина ${ }^{6}$ \\ ${ }^{a}$ Санкт-Петербургский государственный \\ университет \\ Россия, 199034, Санкт-Петербург, \\ Университетская наб., 7/9 \\ ${ }^{\sigma}$ Санкт-Петербургский политехнический \\ университет Петра Великого \\ Россия, 195251, Санкт-Петербург, \\ ул. Политехническая, 29
}

\begin{abstract}
В настоящем исследовании проверяется гипотеза о соотношении между различными типами переводческих ошибок и реакцией изелевой аудитории читателей переводных газетных статей на возможные информационные сдвиги, сопровождающие такие ошибки. Принимая во внимание различие подходов к оценке качества перевода (ОКП), мы анализируем типичнье переводческие очибки с точки зрения логических, эмотивных, оценочных и иных искажений исходной информации, обнаруживаемых в переводном тексте. Предварительнье результать анализа были сопоставлены с комментариями читателей к исходному и переводному текстам соответственно. Разброс читательских реакций оказался не столь значительньлм и лишь частично коррелировал с важными и даже критическими ошибками, допущенными в переводе.
\end{abstract}

Ключевые слова: переводческая ошибка, оченка качества перевода, информационные сдвиги и искажения.

Научная спечиальность: 10.02.00 - лингвистика. 